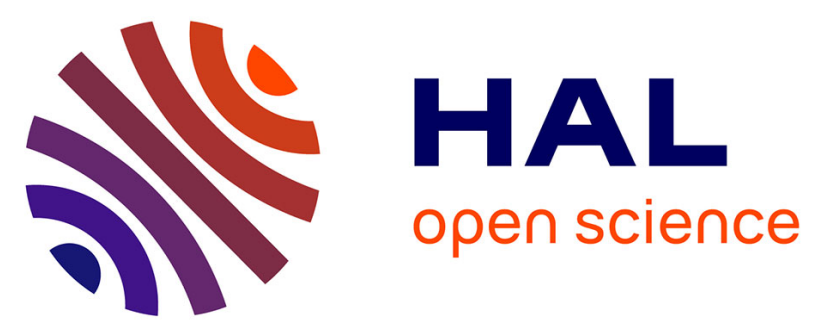

\title{
Spiramycin concentrations in plasma and genital-tract secretions after intravenous administration in the ewe
}

Rafael Garcia Villar, P.L. Toutain, C.C. Cester, M.P. Laurentie, . Laboratoire de Pharmacologie-Toxicologie

\section{- To cite this version:}

Rafael Garcia Villar, P.L. Toutain, C.C. Cester, M.P. Laurentie, . Laboratoire de PharmacologieToxicologie. Spiramycin concentrations in plasma and genital-tract secretions after intravenous administration in the ewe. Journal of Veterinary Pharmacology and Therapeutics, 1990, 13, pp.7-14. hal-02715312

\section{HAL Id: hal-02715312 \\ https://hal.inrae.fr/hal-02715312}

Submitted on 1 Jun 2020

HAL is a multi-disciplinary open access archive for the deposit and dissemination of scientific research documents, whether they are published or not. The documents may come from teaching and research institutions in France or abroad, or from public or private research centers.
L'archive ouverte pluridisciplinaire HAL, est destinée au dépôt et à la diffusion de documents scientifiques de niveau recherche, publiés ou non, émanant des établissements d'enseignement et de recherche français ou étrangers, des laboratoires publics ou privés.

\section{()(1)(2)}

Distributed under a Creative Commons Attribution - ShareAlikel 4.0 International 


\title{
Spiramycin concentrations in plasma and genital-tract secretions after intravenous administration in the ewe*
}

\author{
C. C. CESTER, M. P. LAURENTIE, R. GARCIA-VILLAR \& P. L. TOUTAIN \\ INRA Pharmacology-Toxicology Station, BP 3, F-31931 Toulouse, France
}

Cester, C.C., Laurentie, M.P., Garcia-Villar, R. \& Toutain, P.L. Spiramycin concentrations in plasma and genital-tract secretions after intravenous administration in the ewe. J. vet. Pharmacol. Therap. 13, 7-14.

Uterine infections are associated with reduced fertility in ruminant species. Spiramycin is a macrolide antibiotic potentially active against most of the microorganisms isolated from secretions of infected genital tracts. The present work investigated the ability of systemically administered spiramycin to enter genital secretions, by determining the disposition kinetics of the antibiotic in both plasma and uterine genital secretions. Five healthy ovariectomized ewes were given a single intravenous (i.v.) injection of spiramycin, at a dose of $20 \mathrm{mg} /$ $\mathrm{kg}$. Plasma and genital secretion samples were collected at predetermined intervals for 5 days post-injection. Blood was collected from the jugular vein while mucus was obtained by inserting polyurethane sponges into the vagina. The spiramycin concentration peak in genital-tract secretions was obtained 2.53 $\pm 0.63 \mathrm{~h}$ after the i.v. administration. The mean residence time was significantly longer $(P<0.01)$ in the mucus $(18.31 \pm 3.24 \mathrm{~h})$ than in plasma $(6.99 \pm 2.53 \mathrm{~h})$. An average mucus to plasma ratio of $7.87 \pm 3.00$ was calculated from the area under concentration-time curves covering the period under study. These data indicate that after systemic administration to ewes, spiramycin is rapidly found in genital-tract secretions, at concentrations which are sufficiently high and persistent to suggest its use in the treatment of post-partum uterine infections.

Dr Pierre-Louis Toutain, INRA, Laboratoire de Pharmacologie-Toxicologie, 180 chemin de Tournefeuille, BP 3, F-31931 Toulouse Cédex, France.

\section{INTRODUCTION}

Treatment of ruminant genital-tract infections usually requires the use of antibiotics. The efficacy of the treatment will depend on the antimicrobial concentrations achieved and maintained above minimal inhibitory concentrations at the infection site (Ziv, 1980). In this respect, the disposition of antimicrobials in the genital tract may be influenced by several

*This work is a part of the Doctoral Thesis of Miss Corinne C. Cester. factors including the route of administration (Bretzlaff, 1986). It is currently agreed that concentrations of most antibiotics are greater and more homogeneously distributed in genital-tract tissues after systemic injection than after intrauterine administration (Bretzlaff, 1986).

Macrolide antibiotics such as spiramycin are not currently used in the treatment of metritis, although they diffuse readily into various tissues (Videau, 1978; Bergogne-Bérézin, 1986) and are potentially active against most of the microorganisms isolated from the 
infected genital tract. The apparently exceptional ability of spiramycin to accumulate in tissues and their secretions after systemic administration has not been investigated for the genital tract. Studies on antibiotic disposition in the genital tract of both cows and mares using biopsies of uterine tissues have been reported in the literature (Masera et al., 1980; Haddad et al., 1985, 1986). Such a technique is not applicable to longitudinal studies and an alternative non-invasive method merits consideration. The aim of the present experiments was to evaluate the sheep as an experimental model for long-term and non-invasive studies of antibiotic disposition in the genital tract of ruminants. Results obtained with spiramycin administered by the intravenous route will illustrate the usefulness of this approach.

\section{MATERIALS AND METHODS}

\section{Animals}

Five healthy, adult ewes weighing between 47 and $51 \mathrm{~kg}$ on the day of the study were used. At least 1 month before the experiments the ewes were ovariectomized under aseptic surgical conditions. After surgery, the animals were placed in individual cages and were provided hay, oats and water ad libitum.

In order to control the steroid hormone environment, a polyurethane sponge impregnated with $40 \mathrm{mg}$ of fluorogestone acetate (Chrono-Gest $^{\circledR}$, Intervet, Angers, France) was inserted deep into the vagina for 14 days. Twenty-four hours after sponge withdrawal, $30 \mu \mathrm{g}$ of oestradiol benzoate (Intervet, Angers, France) was injected intramuscularly (gluteus muscle) to improve the production of cervical secretions. The injection of oestradiol benzoate was continued daily for the duration of the study ( 5 days).

One day before the experiment, a catheter filled with heparinized $0.9 \%$ saline solution was inserted into each jugular vein. For the kinetic study spiramycin (Suanovil 20 ${ }^{\circledR}$, Rhône-Mérieux, Lyon, France, containing $3200 \mathrm{iu} / \mathrm{mg}$ of the WHO standard) was injected as a single dose of $20 \mathrm{mg} / \mathrm{kg}$ via one of these catheters. Blood samples $(6 \mathrm{ml})$ were collected from the other catheter before injec- tion (base-line sample, Time 0 ) and at 1, 2, 4, $8,15,30,45,60$ and $90 \mathrm{~min}$, and 2, 3, 4, 6, 8, $10,24,30,48,54,72$, and $96 \mathrm{~h}$ post-injection. All blood samples were collected into heparinized tubes and centrifuged within $30 \mathrm{~min}$ of sampling. Plasma was stored at $-20^{\circ} \mathrm{C}$ until assay. The assays were performed less than 1 month after sample collection.

Genital secretions were collected by a method adapted from that described by Lindsay and Francis (1968): cylindric polyurethane sponges of an average weight of $835 \mathrm{mg}$, $30 \mathrm{~mm}$ in height and $40 \mathrm{~mm}$ in diameter (Chrono-Gest-placebo ${ }^{\circledR}$, Intervet, Angers, France) were inserted deep into the vagina for I h. Baseline mucus samples were obtained during the hour that preceded spiramycin injection (Time 0); then mucus was collected during Hours $1,3,5,7,9,25,31,49,73$ and 97 post-injection. The secretions were squeezed out of the sponge and stored at $-20^{\circ} \mathrm{C}$ until assay.

\section{Antibiotic assay}

Genital secretions and plasma concentrations of spiramycin were determined microbiologically by agar-gel diffusion using Sarcina lutea ATCC 9341 as the test organism. Antibiotic medium No 11, pH 8 (Grove \& Randall, Merck) was poured into assay plates. Just before the assay, mucus samples were centrifuged at $10000 \mathrm{~g}$ for $20 \mathrm{~min}$ and spiramycin was measured in the supernatant. Replicates of each plasma or mucus sample were assayed simultaneously with the corresponding standard curve prepared from either the plasma or mucus of untreated ewes. The level of sensitivity was 0.1 iu corresponding to $0.03125 \mu \mathrm{g}$ of spiramycin $/ \mathrm{ml}$ for both plasma and mucus.

\section{Pharmacokinetic analysis}

The data were analysed with a microcomputer (Compaq Deskpro 386) using a programme for non-linear regression analysis (Yamaoka et al., 1981). Initial estimates were calculated by linear-regression methods (Gibaldi \& Perrier, 1975). 
Plasma pharmacokinetics. Plasma concentrations of spiramycin were fitted to the general polyexponential equation:

$C=\sum_{i=1}^{n} Y_{i} \exp \left(-\lambda_{i} t\right)$

Eqn 1

where $C$ represents spiramycin plasma concentration at time $t ; Y_{i}$ the coefficient of the $i$ th exponential term and $\lambda_{i}$ the exponent of $i$ th exponential term. The number (two or three) of exponents of Equation 1 for each data set was determined by application of the Akaike's information criterion $(A I C)$ as defined by Yamaoka et al. (1978). For non-linear regression analysis, the data points were weighted according to:

$W_{i}=1 / \bar{Y}_{i}^{2}$,

Eqn 2

where $W_{i}$ is the weight and $\bar{Y}_{i}$ is the fitted value of the $i$ th observation.

The relevant pharmacokinetic parameters (elimination half-time, body clearance, etc.) were calculated according to the classic equations associated with compartmental analysis (Gibaldi \& Perrier, 1975). The areas under the plasma concentration-time curves $(A U C)$ were calculated using the linear trapezoidal rule. The infinite part of the curve $\left(A U C_{C_{\text {last }}-\infty}\right)$ was calculated using Equation 3:

$A U C_{C_{\text {last }}-\infty}=C_{\text {last }} / \lambda_{z}$,

Eqn 3

where $C_{\text {last }}$ is the last concentration and $\lambda_{z}$ is the slope of the last phase. As the extrapolated part of the plasma curve was less than $10 \%$, it was possible to estimate the $A U C$ from Time 0 to infinity. It was possible to calculate the body clearance $\left(C l_{\mathrm{B}}\right)$, using the equation:

$$
C l_{\mathrm{B}}=\frac{D}{A U C_{0-\infty}}
$$

Eqn 4

where $D$ is dose.

The mean residence time (MRT) which is the mean time for a molecule of spiramycin to transit through the body, was calculated by the linear trapezoidal rule. In order to compare the plasma $M R T$ and the secretions $M R T$, it was estimated from Time 0 to time corresponding to $C_{\text {last }}$.

Pharmacokinetics in cervical mucus. Cervical mucus spiramycin concentrations were fitted according to equations describing the fate of drugs administered by a non-vascular route, i.e. including an invasion phase (Equation 5):

$$
\begin{aligned}
& C=-\left(y_{1}+y_{2}\right) \exp \left(-\lambda_{\mathrm{A}} t\right)+y_{1} \exp \left(-\lambda_{1} t\right) \\
& +y_{2} \exp \left(-\lambda_{2} t\right)
\end{aligned}
$$

As an alternative, spiramycin kinetics in the mucus were also described by equations including the existence of a lag-time $\left(t_{\text {lag }}\right)$ before the onset of the invasion phase (Equation 6):

$$
\begin{aligned}
C= & -\left(y_{1}+y_{2}\right) \exp \left[-\lambda_{\mathrm{A}}\left(t-t_{\mathrm{lag}}\right)\right] \\
& +y_{1} \exp \left[-\lambda_{1}\left(t-t_{\mathrm{lag}}\right)\right] \\
& +y_{2} \exp \left[-\lambda_{2}\left(t-t_{\mathrm{lag}}\right)\right]
\end{aligned}
$$

Eqn 6

In Equations 5 and 6, $C$ represents spiramycin concentration in the mucus at time $t$, $y_{1}$ and $y_{2}$ the coefficients of the exponential terms, $\lambda_{1}$ and $\lambda_{2}$ the exponents of the exponential terms and $\lambda_{\mathrm{A}}$ the invasion constant. The number of exponents of the equation was determined according to the $A I C$ as mentioned above. For the genital-tract secretions, the $A U C$ was calculated using the trapezoidal linear rule from Time 0 to the time corresponding to $C_{\text {last }}$, because the extrapolated part of the curve was too great (more than $15 \%$ ). The mucus to plasma concentration ratio was calculated using the areas under the concentration-time curves $\left(A U C_{0-C_{\text {last }}}\right)$ for both plasma and mucus, as a means of assessing the passage into and persistence of spiramycin in cervical mucus. The $M R T$ was calculated from Time 0 to the time corresponding to $C_{\text {last }}$.

\section{Statistical analysis}

All values were expressed as means $\pm \mathrm{SD}$ for the five ewes. Harmonic means were calculated for half-time of elimination from plasma and mucus, and for half-time of invasion into the mucus; their SD were computed using a Jackknife technique (Lam et al., 1985). Comparisons between plasma and cervical mucus for elimination half-times and $M R T$ were performed using paired Student's $t$-test. 


\section{RESULTS}

\section{Plasma pharmacokinetics}

The semi-logarithmic plot of spiramycin plasma concentration-time curve after i.v. administration to a representative ewe is shown in Fig. 1. According to the $A I C$, the experimental data for each ewe were better fitted to a triexponential equation (Equation 7):

$$
\begin{aligned}
C_{\mathrm{p}}= & y_{1} \exp \left(-\lambda_{1} t\right)+y_{2} \exp \left(-\lambda_{2} t\right) \\
& +y_{3} \exp \left(-\lambda_{3} t\right),
\end{aligned}
$$

where $C p$ is the spiramycin plasma concentration at time $t ; y_{1}, y_{2}$ and $y_{3}$ are coefficients and $\lambda_{1}, \lambda_{2}$ and $\lambda_{3}$ are exponents of the equation. On this basis, a three-compartment model with elimination from the central compartment was selected to describe the plasma disposition of spiramycin. Individual pharmacokinetic values for the five ewes are shown

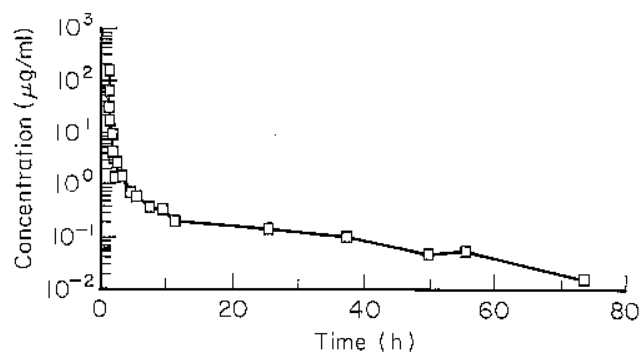

FIG. 1. Semi-logarithmic plot of the spiramycin plasma concentration $(\mu \mathrm{g} / \mathrm{ml})$ vs. time (h) after a single i.v. administration of $20 \mathrm{mg} / \mathrm{kg}$ of spiramycin, in a representative ewe.

in Table I. The mean elimination half-time $\left(t_{1 / 2 \lambda_{3}}=0.693 / \lambda_{3}\right)$ was $14.77 \pm 1.80 \mathrm{~h}$, indicating a slow final disappearance of the antibiotic from blood. This was confirmed by the high value calculated for the $M R T$ which was $8.81 \pm 2.72 \mathrm{~h}$. The body clearance $\left(C l_{\mathrm{B}}=D /\right.$ $\left.A U C_{0-\infty}\right)$ was $0.757 \pm 0.216 \mathrm{l} / \mathrm{h} / \mathrm{kg}$, a value which was three- to fourfold lower than

TABLE I. Pharmacokinetic parameters describing the disposition of spiramycin in plasma after a single

\begin{tabular}{|c|c|c|c|c|c|c|c|}
\hline \multirow[b]{2}{*}{ Parameter } & \multirow[b]{2}{*}{ Units } & & \multicolumn{3}{|l|}{ Ewes } & \multirow[b]{2}{*}{ Mean $\pm \mathrm{SD}$} \\
\hline & & 1 & 2 & 3 & 4 & 5 & \\
\hline$y_{1}$ & $\mu \mathrm{g} / \mathrm{ml}$ & 115.84 & 184.37 & 226.69 & 99.79 & 107.19 & $146.78 \pm 55.97$ \\
\hline$y_{2}$ & $\mu \mathrm{g} / \mathrm{ml}$ & 3.05 & 10.31 & 14.31 & 4.69 & 3.83 & $7.24 \pm 4.87$ \\
\hline$y_{3}$ & $\mu \mathrm{g} / \mathrm{ml}$ & 0.866 & 0.733 & 0.333 & 0.693 & 0.330 & $0.591 \pm 0.245$ \\
\hline$\lambda_{1}$ & $\mathrm{~h}^{-1}$ & 12.98 & 14.09 & 18.59 & 12.19 & 14.88 & $14.55 \pm 2.48$ \\
\hline$\lambda_{2}$ & $h^{-1}$ & 0.496 & 1.158 & 1.351 & 0.990 & 0.836 & $0.966 \pm 0.325$ \\
\hline$\lambda_{3}$ & $\mathrm{~h}^{-1}$ & 0.050 & 0.055 & 0.040 & 0.045 & 0.044 & $0.047 \pm 0.006$ \\
\hline$V_{\mathrm{C}}$ & $1 / \mathrm{kg}$ & 0.166 & 0.102 & 0.087 & 0.190 & 0.183 & $0.146 \pm 0.048$ \\
\hline$V_{\mathrm{d}(\text { area })}$ & $\mathrm{l} / \mathrm{kg}$ & 12.36 & 10.42 & 17.14 & 17.34 & 25.56 & $16.56 \pm 5.86$ \\
\hline$V_{\mathrm{ss}}$ & $1 / \mathrm{kg}$ & 6.832 & 3.257 & 4.435 & 9.497 & 10.358 & $6.876 \pm 3.084$ \\
\hline$C l_{\mathrm{B}}$ & $\mathrm{l} / \mathrm{kg} / \mathrm{h}$ & 0.620 & 0.571 & 0.693 & 0.788 & 1.115 & $0.757 \pm 0.216$ \\
\hline$i_{1,2} \lambda_{3}$ & $\mathbf{h}$ & 13.82 & 12.63 & 17.12 & 15.26 & 15.88 & $14.77 \pm 1.80^{*}$ \\
\hline$M R T_{0-C_{\text {last }}}$ & $\mathbf{h}$ & 9.28 & 4.29 & 4.87 & 9.90 & 6.66 & $6.99 \pm 2.53$ \\
\hline$A U C_{0-\infty}$ & $\mu \mathrm{g} . \mathbf{h} / \mathrm{ml}$ & 32.26 & 35.02 & 30.14 & 25.39 & 18.29 & $28.22 \pm 6.57$ \\
\hline$A U C_{0}-c_{\text {last }}$ & $\mu \mathrm{g} . \mathrm{h} / \mathrm{ml}$ & 31.74 & 34.49 & 29.91 & 25.19 & 18.01 & $27.87 \pm 6.47$ \\
\hline
\end{tabular}
i.v. administration of spiramycin $(20 \mathrm{mg} / \mathrm{kg})$ in five ewes

$y_{1}, y_{2}$ and $y_{3}$, the extrapolated Time 0 plasma drug concentrations of the first, second and third phases of spiramycin disposition, respectively; $\lambda_{1}, \lambda_{2}$ and $\lambda_{3}$, slopes of the first, second and third phases of spiramycin disposition, respectively; $V_{\mathrm{ss}}$, steady state volume of distribution; $V_{\mathrm{d}}$, volume of distribution; $V_{\mathrm{C}}$, volume of the central compartment; $C l_{\mathrm{B}}$, body clearance; $t_{1 / 2 \lambda_{3}}$, half-time of elimination; $M R T$, mean residence time; $A U C$, area under the plasma concentration-time curve.

*Harmonic mean $\pm \mathrm{SD}$. 
hepatic blood flow in this species. The volume of distribution $\left(V_{\mathrm{ss}}\right)$ was exceptionally high $(6.876 \pm 3.084 \mathrm{l} / \mathrm{kg})$, suggesting a considerable diffusion of the antibiotic into the tissues. The volume of the central compartment was $0.146 \pm 0.048 \mathrm{l} / \mathrm{kg}$.

\section{Pharmacokinetics in cervical mucus}

Under oestrogenic domination, a volume of about $1-2 \mathrm{ml}$ of mucus can be collected within $1 \mathrm{~h}$; the semi-logarithmic plot of spiramycin concentration in cervical mucus vs. time after spiramycin i.v. administration to a representative ewe, is shown in Fig. 2. According to the $A I C$, data were better fitted to the aforementioned Equation 4, suggesting that the disposition kinetics of spiramycin in cervical mucus could be described as a bicompartmental model with an invasion phase starting without lag-time.

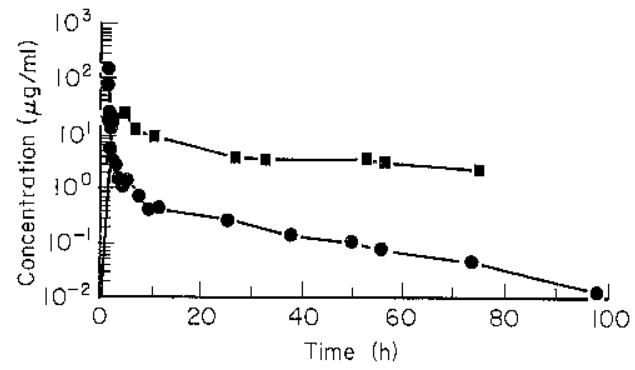

FIG. 2. Semi-logarithmic plot of the spiramycin concentration in plasma (-) and in genital secretions (ם) after a single i.v. administration of spiramycin, in a representative ewe.

The half-time of invasion $\left(t_{1 / 2 \lambda_{\mathrm{A}}}\right)$ was $0.981 \pm 0.366 \mathrm{~h}$, indicating that spiramycin rapidly reached the uterine tissues. The maximal concentration of spiramycin in the mucus $\left(C_{\max }=13.06 \pm 4.25 \mu \mathrm{g} / \mathrm{ml}\right)$ also occurred rapidly $\left(T_{\max }=2.53 \pm 0.63 \mathrm{~h}\right)$. The $M R T_{0-C_{\text {last }}}$ in cervical secretions (18.31 \pm

TABLE II. Pharmacokinetic parameters describing the disposition of spiramycin in cervical mucus after a single i.v. administration of spiramycin $(20 \mathrm{mg} / \mathrm{kg})$ in five ewes

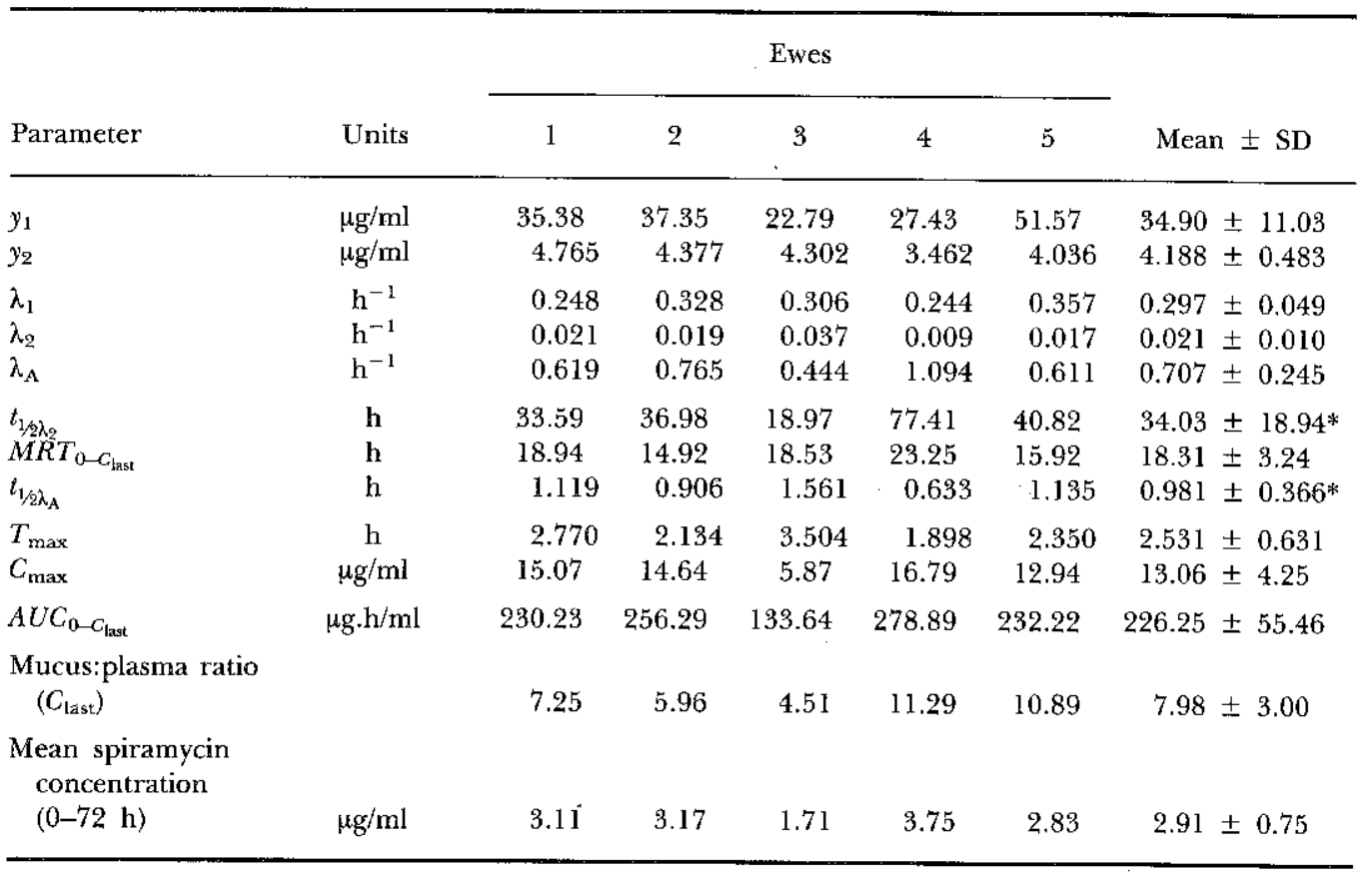

$y_{1}$ and $y_{2}$, extrapolated Time 0 plasma drug concentrations of the first and second phases of spiramycin disposition, respectively; $\lambda_{1}$ and $\lambda_{2}$, slopes of the first and second phases of spiramycin disposition, respectively; $\lambda_{\Lambda}$, constant of absorption; $t_{1 / 2 \lambda_{2}}$, half-time of elimination; $M R T$, mean residence time; $t_{1 / 2 \lambda_{\mathrm{A}}}$, half-time of invasion.

$*$ Harmonic mean \pm SD. 
$3.24 \mathrm{~h})$ was significantly longer $(P<0.01)$ than $M R T_{0-C_{\text {last }}}$ in plasma $(6.99 \pm 2.53 \mathrm{~h})$. The half-time of elimination from the mucus was markedly longer than the plasma half-life but, due to the variability of the data, the difference was not significant $(34.0 \pm 18.9 \mathrm{~h}$ vs. $14.8 \pm 1.8 \mathrm{~h}$ ).

The mucus:plasma $A U C$ ratio was 7.98 \pm 3.00 , indicating that spiramcyin became largely concentrated in cervical mucus and remained at high concentrations throughout the duration of the period under study. Over the first $72 \mathrm{~h}$ following i.v. injection of spiramycin, the mean mucus concentration was $2.91 \pm 0.75 \mu \mathrm{g} / \mathrm{ml}$.

\section{DISGUSSION}

The aim of this study was to assess the ability of spiramycin to pass into genital-tract secretions. The choice of the ewe as the experimental animal model was guided by the similarities which exist between sheep and cattle uterine physiology (motility, secretion) and pathology (Bane, 1980). In horses (Haddad et al., 1985) and cattle (Masera et al., 1980; Haddad et al., 1986) the ability of an antibiotic to accumulate in the genital tract has been tested by repeated endometrial transcervical biopsy. Such a technique is impossible to use in ovine species because the uterine cervix is very narrow. Instead of this, our investigations were performed using a non-invasive technique, namely genital secretion collection by means of polyurethane sponges introduced into the vagina of conscious ewes. This technique was safe and reliable and allowed a great number of samplings in the same animals with minimal disturbance and without modification of the uterine environment (blood flow, tissue irritation) and offered the possibility of a longitudinal study. The polyurethane sponges which were used to collect cervical mucus are normally intended for control of the reproductive cycle in the ewe, and produce minimal irritation. The secretions recovered with the sponges, consist of a pool of fluids originating from the upper genital tract (endometrial, tubal and follicular secretions) (Moghissi, 1973) and are not inflammatory exudates. Most of the secretions originate from the secretory cells of the endocervix and not from the vagina; secretory cells are only present in the extreme anterior vagina at the entrance to the cervix (Restall, 1966). The limitation of the technique is the absence of direct measurement of spiramycin in the uterine tissues, but mucus antibiotic concentration remains relevant when the infection is localized in the superficial endometrium.

The production of cervical mucus requires an appropriate steroid environment (Moghissi, 1973). Briefly, under oestrogen priming, large amounts of watery mucus are produced while under progesterone domination the mucus is thick and of low volume. Therefore, in this study on ovariectomized ewes, oestradiol benzoate was administrated before the onset of and during the sampling session. To avoid oestrogen refraction, the studies were performed after a progestagen (FGA) 14-day impregnation. This schedule, which is similar to that which is recommended for oestrus control in ewes, allowed the collection of considerable amounts of cervical mucus during the 5 days of the study.

Spiramycin disposition in ruminant species has been reported by others. In an investigation in ewes and cows, Ziv (1974) described the plasma kinetics of spiramycin after i.v. injection by a bicompartmental model and reported a half-time of elimination of $14.7 \mathrm{~h}$. More recently, two investigations in cattle (Floc'h et al., 1988; Friis et al., 1988) described the kinetics of this drug with a tricompartmental model and yielded pharmacokinetic parameters which were of the same order as those obtained in the present study in ewes. This indicated that spiramycin disposition was very similar in both ruminant species, thus encouraging use of the ewe for evaluation of the uterine distribution of spiramycin. As in other species, including man (BergogneBérézin, 1986), the volume of distribution of spiramycin was exceptionally high, suggesting the ability of spiramycin to diffuse into the ovine tissues. The systemic administration of spiramycin to ewes rapidly resulted in high concentrations of the antibiotic in genital-tract secretions. The mucus to plasma concentration ratio indicated that spiramycin concentrations were eightfold higher in genital-tract secretions than in plasma. These results were in agreement with those reported by others for bronchial mucus (Bergogne-Bérézin, 
1986; Floc'h, 1988). They provided some experimental evidence suggesting that spiramycin is able to cross the uterine barrier and achieve high and persistent concentrations in genital-tract secretions, even after its disappearance from the blood. These results indicate that plasma concentrations of spiramycin are not always indicative of the potential efficacy of the antibiotic and that actual concentrations in target tissues should be considered together with conventional minimal inhibitory concentrations (MICs).

The efficacy of treatment with a bacteriostatic antibiotic requires the persistence of sufficient concentrations in the genital tract for a sufficient time to allow the elimination of pathogens by uterine defence mechanisms. Actinomyces pyogenes is probably the most harmful pathogen in metritis associated with severe uterine lesions and the formation of purulent discharge (Bane, 1980); the MIC of spiramycin for A. pyogenes (Atkinson, 1986) has been reported to be approximately $3 \mu \mathrm{g} /$ $\mathrm{ml}$. In this study, spiramycin concentrations in genital mucus remained close to $3 \mu \mathrm{g} / \mathrm{ml}$ $(2.91 \mu \mathrm{g} / \mathrm{ml})$ for more than $72 \mathrm{~h}$. The $M I C s$ for other potential pathogens are between 0.5 and $25 \mu \mathrm{g} / \mathrm{ml}$ for Staphylococcus aureus, 2 and $3 \mu \mathrm{g} / \mathrm{ml}$ for Actinomyces spp. (Atkinson, 1986 ) and 0.25 and $8 \mu \mathrm{g} / \mathrm{ml}$ for streptococci (Portier et al., 1979). A final point merits further attention: spiramycin concentration in the mucus was measured after centrifugation so the figures presented here are the minimum amounts present; we do not currently have any information concerning the binding of spiramycin to mucus.

In conclusion, this study indicated that after systemic administration to ewes, spiramycin was rapidly found in genital-tract secretions, at concentrations which were sufficiently high and persistent to suggest its clinical evaluation in the treatment of post-partum uterine infections.

\section{REFERENCES}

Atkinson, B.A. (1986) Species incidence and trends of susceptibility to antibiotics in the United States and other countries: MIC and MBC. In Antibiotics in Laboratory Medicine, 2nd edn. Ed. Lorian, V., p. 1110. Williams and Wilkins, Baltimore.
Bane, A. (1980) Microbiology of the genital tract: etiology of genital infections. Proceedings of the 9 th International Congress of Animal Reproduction and Artificial Insemination, Madrid, 2, 473-484.

Bergogne-Bérézin, E. (1986) The tissue penetration of macrolides with particular reference to the respiratory tract. In Macrolides: a Review with an Outlook on Future Developments. Eds Butzler, J.P. \& Kobayashi, H. pp. 43-53. Excerpta Medica, Amsterdam.

Bretzlaff, K.N. (1986) Factors of importance for the disposition of antibiotics in the female genital tract. In Current Therapy in Theriogenology, 2nd edn. Ed. Morrow, D.A. pp. 34-39. W. B. Saunders Co., Philadelphia.

Floc'h, R., Huét, A.M., Santoul, C. \& Van Gool, F. (1988) Spiramycin concentration in bovine bronchial secretions. Proceedings of the 4th Congress of the European Association for Veterinary Pharmacology E' Toxicology, Budapest, 1, 138.

Friis, C., Erhardsen, E., Bisgaard Madsen, E., Nielsen, P. \& Raun, K. (1988) Spiramycin: oral bioavailability and distribution to lung tissue and bronchial secretions in calves. Proceedings of the 4 th Congress of the European Association for Veterinary Pharmacology \& Toxicology, Budapest, 1, 41.

Gibaldi, M. \& Perrier, D. (1975) One-compartment model. In Pharmacokinetics. Ed. Swarbrick J. pp. 25-27. Marcel Dekker, New York.

Haddad, N.S., Pedersoli, W.M., Carson, R.L. \& Ravis, W.R. (1986) Concentrations of gentamicin in serum, milk, urine, endometrium and skeletal muscle of cows after repeated intrauterine injections. American Journal of Veterinary Research, 47, 1597-1601.

Haddad, N.S., Pedersoli, W.M., Ravis, W.R., Fazeli, M.H. \& Carson, R.L. (1985) Pharmacokinetics of gentamycin at steady-state in ponies: serum, urine and endometrial concentrations. American Journal of Veterinary Research, 46, 1268-1271.

Lam, F.C., Hung, C.T. \& Perrier, D.G. (1985) Estimation of variance for harmonic mean halflives. Journal of Pharmaceutical Sciences, 74, 229 231.

Lindsay, D.R. \& Francis, C.M. (1968) Cervical mucus measurement in ovariectomized ewes as a bioassay of synthetic and phyto-oestrogens. Australian Journal of Agricultural Research, 19, 1069-1076.

Masera, J., Gustafsson, B.K., Afiefy, M.M., Stowe, C.M. \& Bergt, G.P. (1980) Disposition of oxytetracycline in the bovine genital tract: systemic vs intrauterine administration. Journal of the American Veterinary Medical Association, 176, 1099-1 102.

Moghissi, K.S. (1973) Composition and function of cervical secretion. In Handbook of Physiology. Eds Greep, R.O., Astwood, E.B. \& Geiger, S.R. pp. 25-48. American Physiological Society, Washington DC.

Portier, H., Pothier, P. \& Kazmierczak, A. (1979) Macrolides et antibiotiques apparentés. In Phar macologie Clinique. Eds Giroud, J-P., Mathé, G. \& Meyniel, G. pp. 1409-1426. Expansion Scientifique Française, Paris.

Restall, B.J. (1966) Histological observations on the 
14 C. C. Cester et al.

reproductive tract of the ewe. Australian Journal of Biological Sciences, 19, 673-686.

Videau, D. (1978) La spiramycine: bactériologie, pharmacologie, pharmacocinétique et distribution tissulaire. Cahiers de Médecine Vétérinaire, 47, 155-164.

Yamaoka, K., Nakagawa, T. \& Uno, T. (1978) Application of Akaike's information criterion (AIC) in the evaluation of linear pharmacokinetic equations. Journal of Pharmacokinetics and Biopharmaceutics, 6, 165-175.

Yamaoka, K., Tanigawara, Y., Nakagawa, T. \&
Uno, T. (1981) A pharmacokinetic analysis program (MULTI) for microcomputer. Journal of Pharmacobio-Dynamics, 4, 879-885.

Ziv, G. (1974) Profil pharmacocinétique de la spiramycine chez les brebis et les vaches laitières. Cahiers de Médecine Vétérinaire, 43, 371-390.

Ziv, G. (1980) Clinical pharmacology of antibacterial drugs and their application in treating bovine metritis. In Current Therapy in Theriogenology. $\mathrm{Ed}$. Morrow, D.A. pp. 25-45. W. B. Saunders Co., Philadelphia. 